\title{
Carrying capacity assessment for the Greek islands of Kalymnos, Kos and Rhodes
}

\author{
B. S. Tselentis ${ }^{1}$, D. G. Prokopiou ${ }^{1} \&$ M. Toanoglou ${ }^{2}$ \\ ${ }^{I}$ Department of Maritime Studies, University of Piraeus, Greece \\ ${ }^{2}$ University of Surrey, $U K$
}

\begin{abstract}
Carrying capacity assessment has become an indispensable tool for formulating policy and strategies in the tourist industry worldwide. It is well known that Greece depends heavily on the tourist trade, as this has, in recent years, become the main economic activity in many of the Greek islands. The transformation of local economies from primary and secondary production to tertiary has, over the years, substantially altered the business environment in which such an activity takes place. Many studies have shown that the tourist product is a blend of ecological, social and economic sub-systems, operable in the area of interest. For the Greek Islands, environment, both natural and man made, plays a leading role in the sustainable development of the industry. It is the purpose of this paper to apply the principles of carrying capacity assessment to three Greek islands, differing in their tourist development, in an effort to highlight the importance of such a tool in developing long-term sustainable policies for such communities.
\end{abstract}

\section{Introduction}

The World Tourism Organisation (WTO) proposes the following definition of carrying capacity: "The maximum number of people that may visit a tourist destination at the same time, without causing destruction to the physical, economic, socio-cultural environment and an unacceptable decrease in the quality of visitors' satisfaction" [1].

Today, controlling tourist growth has become a central policy issue for the tourist trade [2] and it is noteworthy that carrying capacity assessment has become an important tool for facilitating planning and developing policy in the industry [3]. 
Relevant carrying capacity indicators have been developed and categorised into three groups: 1. physical-ecological, 2. infrastructural and 3. Sociologicalpsychological [4]. It is highly topical to develop and integrate such indicators [5] into the planning process of the Greek tourist business, and more specifically to the island tourist trade, on which the Greek economy depends so heavily upon. It is believed that, through this process, a realistic sustainable scenario for tourist development could be proposed for such areas.

\section{Basic population characteristics and employment figures for Kalymnos Kos and Rhodes islands}

\subsection{Population}

As indicated by Table 1 the population of Kos and Rhodes has increased considerably during the period of $1950-2001$, representing a rise of about $20 \%$. This increase in population is more pronounced for the town of Kos and Rhodes. The population of Kalymnos has increased at a lower rate than the population of the other two islands.

Table 1: $\quad$ Population characteristics (2001) in Kalymnos, Kos and Rhodes.

\begin{tabular}{|l|c|l|l|}
\hline & Population & Area $\left(\mathrm{km}^{2}\right)$ & Density inhabitants $/ \mathrm{km}^{2}$ \\
\hline KALYMNOS & 16.441 & 110,8 & 148,38 \\
\hline KOS & 30.947 & 290,2 & 106,64 \\
\hline RHODES & 117.007 & 1398 & 83,65 \\
\hline
\end{tabular}

Table 2: $\quad$ Population growth (1951-2001) in Kalymnos, Kos and Rhodes.

\begin{tabular}{|l|l|l|l|l|l|l|c|}
\hline & 1951 & 1961 & 1971 & 1981 & 1991 & 2001 & $\begin{array}{c}\text { Rate \% } \\
1991-2001\end{array}$ \\
\hline KALYMNOS & 13.712 & 14.249 & 13.281 & 14.457 & 15.842 & 16.441 & 3,78 \\
\hline KOS & 19.076 & 18.187 & 16.650 & 20.350 & 26.379 & 30.947 & 17,32 \\
\hline RHODES & 59.807 & 63.954 & 66.609 & 87.833 & 98.181 & 117.007 & 19,17 \\
\hline
\end{tabular}

\subsection{Employment}

Analyzing the employment figures of these three islands it is obvious that the economies of Kos and Rhodes are based on tourism. This transformation happened in the late 1970s, as a shift from primary and secondary to tertiary production. In Kalymnos the characteristics of employment is different, $40 \%$ work in the primary and in the secondary sectors of economy. 
Table 3: $\quad$ Employment figures for Kalymnos, Kos and Rhodes.

\begin{tabular}{|l|c|c|c|c|}
\hline \multicolumn{1}{|c|}{ Region } & Year & Primary & Secondary & Tertiary \\
\hline NATIONAL & 1981 & $29,2 \%$ & $30,5 \%$ & $40,4 \%$ \\
\hline NATIONAL & 1991 & $19,6 \%$ & $25,4 \%$ & $55,0 \%$ \\
\hline NATIONAL & 2001 & $15,2 \%$ & $22,9 \%$ & $61,8 \%$ \\
\hline DODECANESE & 1981 & $13,9 \%$ & $27,4 \%$ & $58,7 \%$ \\
\hline DODECANESE & 1991 & $7,9 \%$ & $23,6 \%$ & $68,5 \%$ \\
\hline DODECANESE & 2001 & $7.0 \%$ & $19 \%$ & $74 \%$ \\
\hline KALYMNOS & 2001 & $16.2 \%$ & $23.8 \%$ & $59.8 \%$ \\
\hline KOS & 1991 & $7.8 \%$ & $23.8 \%$ & $68.25 \%$ \\
\hline KOS & 2001 & $5,0 \%$ & $17.0 \%$ & $78.0 \%$ \\
\hline RHODES & 1981 & $10,2 \%$ & $25,6 \%$ & $64,3 \%$ \\
\hline RHODES & 1991 & $6,0 \%$ & $22,7 \%$ & $71,3 \%$ \\
\hline RHODES & 2001 & $7.0 \%$ & $19.0 \%$ & $74.0 \%$ \\
\hline
\end{tabular}

\section{Tourist indicators}

\subsection{Tourist development}

Tourist development in Kos started in the early 1970s. In 1977, the number of hotels in Kos amounted to 17 whereas in 1986 these rose to 182. Tables 4 and 5 describe the increase in tourist infrastructure. In 1979 hotels in Kos provided 3.471 rooms for rent, whereas by 2004 there were 271 with an estimated capacity of about 60,000 beds.

Table 4: $\quad$ Bed capacity in Rhodes related to area and local population.

\begin{tabular}{|l|c|c|c|c|c|}
\hline Municipalities & Inhabitants & Total beds & $\begin{array}{c}\text { Bed per } \\
\text { residents }\end{array}$ & $\begin{array}{c}\text { Area } \\
(\mathrm{Sq} \\
\mathrm{Km})\end{array}$ & Bed per Sq Km \\
\hline ARHAGELOS & 7.758 & 1.673 & 0.21 & 115,4 & 14,5 \\
\hline ATTAVIROS & 3.214 & 90 & 0,02 & 234,4 & $0 ., 38$ \\
\hline AFANDOU & 6.557 & 8.340 & 1,27 & 46,1 & 180.9 \\
\hline IALYSOS & 10.275 & 17.557 & 1,70 & 16,7 & 1051.3 \\
\hline KALLITHEA & 9.979 & 21.561 & 2,16 & 119,8 & 180.0 \\
\hline KAMIROS & 5.315 & 295 & 0,05 & 211 & 1.4 \\
\hline LINDOS & 3.719 & 9.084 & 2,44 & 179 & 50.7 \\
\hline SOUTH RHODES & 4.315 & 3.770 & 0,87 & 379,1 & 9.9 \\
\hline PETALOUDES & 11.858 & 4.269 & 0,36 & 89,3 & 47.8 \\
\hline RHODES TOWN & 54.802 & 18.327 & 0,33 & 19,5 & 939.8 \\
\hline RHODES TOTAL & 117.007 & 84.912 & 0,72 & 1.400 & 60.6 \\
\hline
\end{tabular}

In Rhodes, tourist development started in the early 1960s in the northern part of the island, known as the "The Northern Triangle". By 1971, hotels and rooms for rent were estimated to about 20,000. In 2004 this capacity has risen to 120,000. In 1960 there were 27 Hotels in Rhodes, in 1980164 and now 510.

Kalymnos started developing in the early 1990s, but until recently, has not exceeded 5,000 beds in capacity.

As indicated by table 7 Kos has the largest number of bed capacity per square kilometer, compared to the other two islands. 
Table 5: Bed capacity in Kos and Kalymnos related to area and local population.

\begin{tabular}{|l|c|c|c|c|c|}
\hline \multicolumn{7}{|c|}{ Municipalities } & $\begin{array}{c}\text { Inhabi } \\
\text { tants }\end{array}$ & Total beds & $\begin{array}{c}\text { Bed per } \\
\text { residents }\end{array}$ & $\begin{array}{c}\text { Area } \\
(\mathrm{Sq} \\
\mathrm{Km})\end{array}$ & $\begin{array}{c}\text { Bed per } \\
\text { Sq Km }\end{array}$ \\
\hline DIKAIOS & 6.094 & 8.868 & 1,4 & 62,6 & 142.6 \\
\hline HERACLEIDON & 6.963 & 18.045 & 2,5 & 157,4 & 114,6 \\
\hline KOS TOWN & 17.890 & 24.872 & 1,39 & 65 & 383,6 \\
\hline KOS TOTAL & $30 . .947$ & 51.695 & 1,67 & 285 & 181,3 \\
\hline \multicolumn{7}{|c|}{ BED CAPACITY IN KALYMNOS } \\
\hline KALYMNOS & 16.500 & $5.000[6]$ & 0,30 & 110,8 & 45.1 \\
\hline
\end{tabular}

Table 6: Distribution of tourist hospitality enterprises.

\begin{tabular}{|l|c|c|}
\hline & Estimated total tourist capacity in beds & Beds per sq kilometre \\
\hline KALYMNOS & 5.000 & 45,1 \\
\hline KOS & 70.000 & 241,21 \\
\hline RHODES & 120.000 & 85,8 \\
\hline
\end{tabular}

Table 7: $\quad$ Tourist development in Kalymnos, Kos and Rhodes.

\begin{tabular}{|l|r|r|r|r|r|r|}
\hline & \multicolumn{2}{|c|}{ KALYMNOS } & \multicolumn{2}{c|}{ KOS } & \multicolumn{2}{c|}{ RHODES } \\
\hline Year & \multicolumn{1}{|c|}{ Units } & \multicolumn{1}{c|}{ Beds } & \multicolumn{1}{c|}{ Units } & \multicolumn{1}{c|}{ Beds } & \multicolumn{1}{c|}{ Units } & \multicolumn{1}{c|}{ Beds } \\
\hline 1935 & & & & & 3 & \\
\hline 1960 & & & & & 27 & 1875 \\
\hline $1979-80$ & & & 17 & 3.431 & 164 & 27.192 \\
\hline 1988 & 24 & 844 & 179 & 13.814 & 320 & 40.334 \\
\hline 1993 & 47 & 1.750 & 246 & 23.320 & 431 & 60.742 \\
\hline 1999 & 46 & 1.928 & 266 & 31.672 & 494 & 71.458 \\
\hline 2006 & 45 & 1.946 & 288 & 41.512 & 510 & 74.207 \\
\hline
\end{tabular}

Table 8: $\quad$ Closed hotels in Kalymnos, Kos and Rhodes [7].

\begin{tabular}{|l|c|}
\hline KALYMNOS & 9 \\
\hline KOS & 20 \\
\hline RHODES & 76 \\
\hline
\end{tabular}

Table 9: Other tourist capacity (rooms to let and bungalows) development in Kalymnos, Kos and Rhodes.

\begin{tabular}{|c|c|c|c|c|c|c|}
\hline & \multicolumn{2}{|c|}{ KALYMNOS } & \multicolumn{2}{c|}{ KOS } & \multicolumn{2}{c|}{ RHODES } \\
\hline & Units & Beds & Units & Beds & Units & Beds \\
\hline 1982 & & & & & & 909 \\
\hline 1989 & & 594 & & 7.760 & & 11.769 \\
\hline 1993 & 143 & 1.771 & 551 & 10.211 & 797 & 33.731 \\
\hline 1999 & 81 & 699 & 433 & 7.581 & 853 & 13.489 \\
\hline 2004 & & 3.054 & 482 & 4.532 & & 14.852 \\
\hline
\end{tabular}


Economic crisis has taken place in tourist enterprises; a lot of hotels have stopped working (Table 8). Today in Kos there are 7 new five-star hotels under construction [8]. They are starting operations in April 2006. Our survey showed that, local authorities could not, as yet, estimate the real capacity.

\subsection{Tourist arrivals, related to local population, during high and low season}

As indicated by Table 10 the island of Kos has the most arrivals and overnight stays per 100 inhabitants compared to the other two islands.

As indicated by Table 11, total airport arrivals do not compare to hotel arrivals, indicating that other lodgings are operable on the island, such as nonlicensed hotels and rooms to let, as well as camping facilities that are not taken into account in the official statistics.

Table 10: Tourists related to residents in 2003 - arrivals in hotels and overnight stays.

\begin{tabular}{|l|c|c|c|c|}
\hline & $\begin{array}{l}\text { Low season, } \\
\text { October arrivals } \\
\text { per } \\
\text { inhabitants }\end{array}$ & $\begin{array}{l}\text { High season, } \\
\text { August arrivals } \\
\text { per } \\
\text { inhabitants }\end{array}$ & $\begin{array}{l}\text { Low season, } \\
\text { overnight stays } \\
\text { per day/ 100 } \\
\text { inhabitants }\end{array}$ & $\begin{array}{l}\text { High season, } \\
\text { overnight stays } \\
\text { per day/ 100 } \\
\text { inhabitants }\end{array}$ \\
\hline KALYMNOS & 1,95 & 118,4 & 0,1 & 1,95 \\
\hline KOS & 113,5 & 400,4 & 38,7 & 1,16 \\
\hline RHODES & 83 & 183,3 & 27 & 54,3 \\
\hline
\end{tabular}

Table 11: Comparison of airport arrivals to hotel arrivals.

\begin{tabular}{|l|c|c|c|c|}
\hline & $\begin{array}{l}\text { Arrivals in the } \\
\text { airports, } \\
\text { October }\end{array}$ & $\begin{array}{l}\text { Arrivals in the } \\
\text { airports August }\end{array}$ & $\begin{array}{l}\text { Arrivals in hotels } \\
\text { and other rooms, } \\
\text { October }\end{array}$ & $\begin{array}{l}\text { Arrivals in hotels } \\
\text { and other rooms, } \\
\text { August }\end{array}$ \\
\hline KALYMNOS & - & - & 322 & 2.484 \\
\hline KOS & 124.832 & 149.952 & 35.137 & 12.394 \\
\hline RHODES & 143.528 & 298.752 & 97.403 & 214.585 \\
\hline
\end{tabular}

Table 12: $\quad$ Hotel arrivals related to local residents.

\begin{tabular}{|l|c|c|c|c|}
\hline & $\begin{array}{c}\text { Low season, } \\
\text { tourists in } \\
\text { October }\end{array}$ & $\begin{array}{c}\text { High season, } \\
\text { tourists in } \\
\text { August }\end{array}$ & $\begin{array}{c}\text { Low season, } \\
\text { tourists per } 100 \\
\text { inhabitants }\end{array}$ & $\begin{array}{c}\text { High season, } \\
\text { tourists per } 100 \\
\text { inhabitants }\end{array}$ \\
\hline KALYMNOS & 400 & 2.250 & 2,4 & 13,6 \\
\hline KOS & 53.000 & 137.000 & 170 & 441 \\
\hline RHODES & 117.000 & 256.000 & 100 & 218 \\
\hline
\end{tabular}

\subsection{Seasonal population}

The occupancy at low season for Kalymnos is nearly zero, whereas Kos and Rhodes have a much higher value, indicating that Kalymnos does not have tourist economies of scale. It is thus inferred that the tourist season in Kalymnos is mainly July and August. 
Table 13: Total seasonal population (non formal data).

\begin{tabular}{|l|c|c|l|l|}
\hline & Residents & Bed capacity & $\begin{array}{l}\text { low season } \\
\text { population }\end{array}$ & $\begin{array}{l}\text { High season } \\
\text { population }\end{array}$ \\
\hline & & $\begin{array}{l}\text { Hotels and other } \\
\text { rooms }\end{array}$ & $\begin{array}{l}\text { Hotel occupancy } \\
50 \%\end{array}$ & $\begin{array}{l}\text { Hotel -occupancy } \\
100 \%\end{array}$ \\
\hline KALYMNOS & 16.411 & 5.000 & - & 21.411 \\
\hline KOS & 30.947 & 70.000 & 65.947 & 100.947 \\
\hline RHODES & 117.007 & 120.000 & 167.007 & 217.007 \\
\hline
\end{tabular}

\subsection{Airport and port arrivals}

Table 14: $\quad$ Port arrivals in Kalymnos, Kos and Rhodes.

\begin{tabular}{|l|r|r|r|r|r|r|}
\hline & 1999 & 2000 & 2001 & 2002 & 2003 & 2004 \\
\hline KALYMNOS & 86.360 & 90.655 & 94.316 & 64.896 & 77.132 & 45.363 \\
\hline KOS & 207.096 & 207.096 & 226.283 & 105.248 & 125.249 & 130.452 \\
\hline RHODES & 305.465 & 320.738 & 332.889 & 237.710 & 201.399 & 267.007 \\
\hline
\end{tabular}

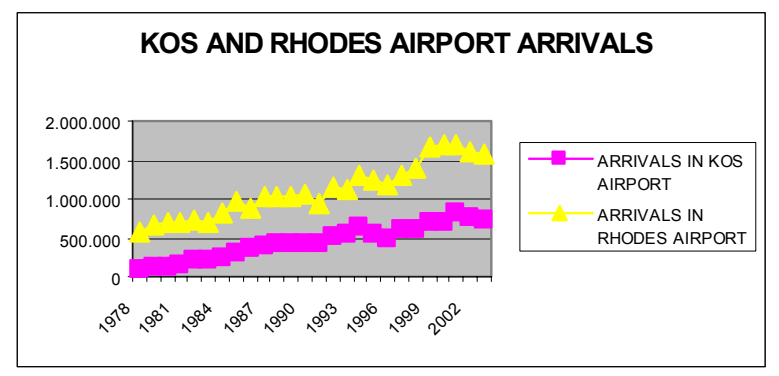

Figure 1: Airport arrivals.

\section{Environmental indicators}

The south of Rhodes is considered the most environmentally sensitive region of all three islands. This area is now characterized as a saturated region due to the high tourist numbers visiting and the capacity of offered services, leading to the highest concentration experienced on the island.

\subsection{Beach impact factor}

With this indicator we analyse the pressures facing the coastal environment, as they describe the concentration of people visiting and using the facilities of the coastal area, and especially beaches. 
Table 15: $\quad$ Beach impact factor in Kalymnos, Kos and Rhodes.

\begin{tabular}{|c|c|c|c|c|c|c|}
\hline Municipalities & $\begin{array}{c}\text { Beach } \\
\text { length }(\mathrm{m})\end{array}$ & Inhabitants & $\begin{array}{l}\text { Hotel } \\
\text { beds }\end{array}$ & $\begin{array}{c}\text { Rooms } \\
\text { to let } \\
\text { (beds) }\end{array}$ & $\begin{array}{c}\text { Total seasonal } \\
\text { population }\end{array}$ & $\begin{array}{c}\text { Beach impact } \\
\text { factor } \\
\text { (people } / \mathrm{m} \text { of } \\
\text { beach) }\end{array}$ \\
\hline \multicolumn{7}{|c|}{ RHODES [9] } \\
\hline ARHAGELOS & 6 & 7.758 & 1.044 & 629 & 9.437 & 1,6 \\
\hline ATTAVIROS & 3 & 3.214 & 79 & 11 & 3.307 & 1,1 \\
\hline AFANDOU & 12 & 6.557 & 6.673 & 1.667 & 14.909 & 1,2 \\
\hline IALYSOS & 8 & 10.275 & 16.606 & 951 & 27.840 & 3,5 \\
\hline KALLITHEA & 10 & 9.979 & 16.828 & 4.733 & 31.550 & 3,2 \\
\hline KAMIROS & 16 & 5.315 & 127 & 168 & 5.626 & 0,4 \\
\hline LINDOS & 9 & 3.719 & 5.516 & 3.568 & 12.812 & 1,4 \\
\hline SOUTH RHODES & 35 & 4.315 & 3.357 & 359 & 8.101 & 0,2 \\
\hline PETALOUDES & 12 & 11.858 & 3.357 & 912 & 16.139 & 1,3 \\
\hline RHODES TOWN & 5 & 54.802 & 16.575 & 1.752 & 73.134 & 14,6 \\
\hline RHODES ISLAND & 151 & 117.007 & 70.162 & 14.750 & 201.919 & 2,8 \\
\hline $\begin{array}{l}\text { RHODES EXCEPT } \\
\text { RHODES CITY }\end{array}$ & 146 & 62.205 & 53.587 & 12.998 & 128.785 & 1,5 \\
\hline NORTH TRIANGLE & 47 & 93.471 & 56.682 & 9.103 & 163.572 & 4,3 \\
\hline \multicolumn{7}{|c|}{$\operatorname{KOS}[10]$} \\
\hline DIKAIOS & 8.1 & 6.094 & 8.242 & 626 & 14.962 & 1,8 \\
\hline HERACLEIDON & 24.3 & 6.963 & 14.197 & 3.848 & 25.008 & 1,02 \\
\hline KOS TOWN & 6.5 & 17.890 & 19.178 & 5.604 & 42.672 & 6,5 \\
\hline KOS TOTAL & 38.9 & 30.947 & 41.617 & 10.078 & 82.642 & 2,18 \\
\hline \multicolumn{7}{|c|}{ KALYMNOS } \\
\hline KALYMNOS & 8 & 16.500 & 1.946 & 2.954 & 21.500 & 2,68 \\
\hline
\end{tabular}

North Triangle of Rhodes: Municipalities of Rhodes, Ialysos, Petaloudes, Afandou and Kallithea.

Kalymnos Island, with a total of 8 kilometres of beach, does not face the same pressure on its coastal regions (beach impact factor $=2.68$ persons per metre of beach) as the Northern Triangle of Rhodes (4.3) and town of Kos (6.5).

Table 16: Beach impact factor, high and low season.

\begin{tabular}{|l|l|c|c|c|}
\hline \multicolumn{2}{|c|}{} & KALYMNOS & KOS & RHODES \\
\hline $\begin{array}{l}\text { Tourists per } \\
\text { kilometer of beach }\end{array}$ & High season & 625 & 1799.4 & 821.9 \\
\cline { 2 - 5 } & Low season & - & 899.7 & 410.9 \\
\hline
\end{tabular}

Table 17: Blue flags in beaches and marinas.

\begin{tabular}{|l|l|l|}
\hline & Beaches & Marinas \\
\hline KALYMNOS & 0 & 0 \\
\hline KOS & 9 & 1 \\
\hline RHODES & 35 & 0 \\
\hline
\end{tabular}

Rhodes seems to be the island with the highest number of beaches with Blue Flag certification, indicating that serious attempts have been made to protect the environment and possibly increase competitiveness in offered tourist services. Kalymnos, on the other hand, does not have any beaches with Blue Flag certification, a result that agrees well, with other indicators, presented earlier, showing a relatively slow tourist development. 


\subsection{Natural environment}

In Kalymnos, Kos and Rhodes there are no established national parks. Nevertheless, we have three environmentally protected areas, which belong to the "Natura" network. These environmentally protected areas, based on the "Natura" program do not, as yet, have a management scheme and are not governed by a specific establishment or organization. Two of these areas are in Rhodes and one is in Kos.

Table 18: Environmentally protected areas in Kalymnos, Kos and Rhodes.

\begin{tabular}{|l|l|l|l|l|}
\hline & & Category & $\begin{array}{l}\text { Law } \\
\text { regulations }\end{array}$ & $\begin{array}{l}\text { Organization for } \\
\text { administration }\end{array}$ \\
\hline CYPRESS TREE FOREST & RHODES & $\begin{array}{l}\text { Protected natural } \\
\text { monument }\end{array}$ & NO & NO \\
\hline PLANE TREE OF HIPPOCRATES & KOS & $\begin{array}{l}\text { Protected natural } \\
\text { monument }\end{array}$ & NO & NO \\
\hline $\begin{array}{l}\text { PROFITIS ILIAS, EPTA } \\
\text { PHGES,PETALOUDES }\end{array}$ & RHODES & Natura network area & NO & NO \\
\hline $\begin{array}{l}\text { LOUROS COAST, PSALIDI } \\
\text { LAKE, DIKAIOS MOUNTAIN, } \\
\text { ALYKH }\end{array}$ & KOS & Natura network area & NO & NO \\
\hline $\begin{array}{l}\text { AKRALYTIS, ARMENISTIS, } \\
\text { ATTAVIROS }\end{array}$ & RHODES & Natura network area & NO & NO \\
\hline
\end{tabular}

Table 19: Threatened species in Rhodes and total expenditure for the management of protected areas.

\begin{tabular}{|l|l|l|l|l|}
\hline FAUNA & Population & Condition & $\begin{array}{l}\text { Protection } \\
\text { organization }\end{array}$ & $\begin{array}{l}\text { Grants for } \\
\text { protection }\end{array}$ \\
\hline Rodian deep & $100-150[13]$ & Threatened & NO & $?$ \\
\hline Rodian ponny[14] & $6[15]$ & Threatened & YES & $15.000 €$ \\
\hline Gizani fish [16] & $100-150$ & Threatened & NO & $?$ \\
\hline
\end{tabular}

The Natura area in Kos Island, houses an important bird area of Greece, the Psalidi wetland area [9]. Many different migratory birds visit this place within the year. This wetland, however, is situated in the suburbs of the town of Kos, which is a main tourist area. As a result, that important ecological area is under threat, and the Municipality of Kos has introduced management schemes to control this tourist area. The regulations that comprise the management options adopted, have been developed and implemented by the Ministry of Environment. It is said that the establishment of a Local Managing Authority will take place in a few months. In Rhodes, one of protected areas is the well-known area called the "Butterfly valley" which is managed by the local municipality. Rhodian deer and little pony from Archagelos are species of special interest to the island and many efforts are underway to ensure that both survive excessive human intervention. The indicators presented below, indicate the number of threatened species in proportion to the total number of native species [10]. 


\subsection{Garbage and waste management}

Urban waste management (solid and liquid) on all three islands is characterized by the lack of efficiency. Only the large urban centers fulfill the basic requirements of modern waste management installations. It is interesting to note that other smaller settlements do not even have a complete urban waste collection network.

Table 20: Urban waste and garbage management in Kalymnos, Kos and Rhodes islands.

\begin{tabular}{|l|r|l|r|r|l|}
\hline Municipality & Inhabitants & $\begin{array}{l}\text { Urban waste } \\
\text { treatment plant }\end{array}$ & $\begin{array}{l}\text { Percentage of } \\
\text { waste treated }\end{array}$ & Availability & Garbage management \\
\hline ARHAGELOS & 3.214 & N.R..T.P & None & & Dump place \\
\hline ATAVIROS & 6.557 & 1 & $30 \%$ & 3000 & Dump place \\
\hline AFANDU & 10.275 & N.R..T.P & None & & Scrap heap \\
\hline IALYSOS & 9.979 & N.R..T.P & None & & Place of sanitary burial \\
\hline KALLITHEA & 5.315 & N.R..T.P & $30 \%$ & & Place of sanitary burial \\
\hline KAMIROS & 3.719 & 1 & & & Place of sanitary burial \\
\hline LINDOS & 4.315 & 1 & $30 \%$ & & Scrap heap \\
\hline SOUTH RHODES & 11.858 & NO & & & Scrap heap \\
\hline PETALOUDES & 54.802 & \multicolumn{1}{|l|}{ YES } & $90 \%$ & 14000 & Place of sanitary burial \\
\hline RHODES TOWN & 7.758 & N.R..T.P & Place of sanitary burial \\
\hline RHODES GENERAL & 117.007 & \multicolumn{2}{|c|}{$70 \%$ of all the island } & & \\
\hline KOS ISLAND & 30.947 & \multicolumn{1}{|l|}{ YES } & $72 \%$ & & Place of sanitary burial \\
\hline KALYMNOS & 16.441 & NO & $0 \%$ & & Dump place \\
\hline
\end{tabular}

NRTP: North Rhodes Urban Waste Treatment Plant, Vodi Place

\section{Conclusions}

In this paper an attempt was made to present selected carrying capacity assessment indicators for three Greek islands that differ in their tourist development, as well as draw some conclusions as to how these indicators can assist in developing sustainable tourist development policies, in island settings.

The data presented in the form of tourist infrastructure indicators, highlights the fact that the municipalities of the town of Rhodes $\left(939,8 \mathrm{beds} / \mathrm{Km}^{2}\right)$, Ialysos (1051,3 beds $/ \mathrm{Km}^{2}$ ) and Kos town (339 beds $/ \mathrm{Km}^{2}$ ) have the higher tourist concentration in terms of accommodation. Comparing these three regions to other municipalities such as that of Kalymnos and other municipalities of Kos and Rhodes, we conclude that the former ones are already saturated, and have no real capacity for further development in accommodating a greater number of visitors. Taking into account other indicators (employment, economy characteristics etc) the conclusion is reached that these saturated areas can progress towards developing quality and alternative tourist services. Areas that are not as yet developed, should not necessarily develop along the same lines as the major tourist attraction areas, but should, at this stage of their development, plan ahead in order that planning and policy development and implementation, lead to a truly competitive and environmentally sound business. In this respect the area of South Rhodes is trying to further develop tourism, by financing cultural and other alternative tourist developments:[11]. 
- It is interesting to note that the economies of Rhodes and Kos are almost exclusively based on tertiary activities, whereas in Kalymnos the economy resembles that of previous years for Rhodes and Kos and consists (by 50\%)of both secondary and tertiary production levels. This is also another fact that can support policies leading to a more controlled and environmentally beneficial tourist development of the island of Kalymnos.

- Hotel occupancy indicators for Kos and Rhodes, showing 50\% during low season and $100 \%$ in the peak periods, combined to the fact that the tourist season in Kalymnos is mainly during the months of August and July, lead us to conclude that the tourist industry should aim at extending the tourist season to include more months, and probably visitors with varied interests and expectations of the beautiful islands [12].

- The fact that domestic and international arrivals in October at Kos (125.000 passengers) compare well to those for Rhodes (144.000 passengers), whereas the numbers for high season are double for Rhodes, (144.000 for Kos and 298.000 for Rhodes), indicate that Kos, through local tourism organizations, has achieved a better balance between high and low season tourist figures, by what seems to be policies and measures aimed at alternative tourist attractions thus achieving an better quality and extended tourist season [13].

- Environmental indictors, indicate that the transformation from a low quality, high numbers tourist trade, to an alternative, high quality one, will not be easy, since waste management systems are insufficient in dealing with urban and solid waste. It is well known that, such inadequacies have serious environmental consequences, and hinder any attempts towards developing a tourist industry based on quality.

- Calculated coastline impact indicators, indicate that the island of Kalymnos (with a total of $8 \mathrm{~km}$ of beach) does not face the same pressure on its coastal regions as the Northern Triangle of Rhodes and town of Kos. It is without surprise that these two areas have the highest concentration and visiting rate of tourists in all three islands.

- The increasing public interest in nature and landscape preservation is, today, considered a major positive factor in the tourist development process. It is true that the growing influx of visitors can exert strong pressures on fragile ecosystems [14]. In the Northern part of the island of Rhodes, local inhabitants have been demanding that an alternative tourist development strategy should be implemented in this area. However an area with environmentally sensitive areas should have an effective management scheme-[15] and be run under a modern and highly sophisticated regime.

\section{Acknowledgements}

We would like to express our thanks for their help and collaboration to: Dimitra Tselou, economist, University of Piraeus, Dimitris and Catherine Neamonitis, tourist business managers in Kos, Nikos Kantazis, Architect Kos, Spyros Gavanozis Hellenic Civil Aviation Authority, Loucas Mastis, Chief Editor "Rodiaki" newspaper, Manos Anastasiadis painter, Rhodes, Litsa Papathanassi 
Director of TUI Rhodes-Vice President of SKǍL international, Mr Petsis, Department of Tourism, Periphery of South Aegean, Rhodes and Paraschos, Vasiliki, Maria and Matia Zouglas.

\section{References}

[1] UNEP/MAP/PAP, 1997

[2] Coccosis H and Mexa A, 'The challenge of Tourism Carrying Capacity Assessment', Ashgate 2004

[3] Fernando J Garrigós Simón, Y. Narangajavana, and D. Palacios-Marqués. 'Carrying capacity in the tourism industry: a case study of Hengistbury Head'

[4] Jurincic I 'Carrying capacity assessment of Slovene Istria for tourism', $2^{\text {nd }}$ International Conference on sustainable planning and development Bologna 2005, Wessex Institute of Technology

[5] Zannou V, 'Guide of Socio-Economic Studies for the Integrated Management of the Water Environment' 1999

[6] Municipality of Kalymnos 2006-02-21

[7] Mr Petsis, 'Department of Tourism, Periphery of South Aegean, Rhodes',

[8] Sofou M, Kos Hotel Association. Personal communication 2006-02-15

[9] Hellenic Ornithological Society, www.ornithologiki.gr

[10] Indicators for the sustainable development in the Mediterranean region, Blue Plan - PNUE 2000

[11] 'Rodiaki' newspaper 2006-02-12

[12] Prokopiou DG and Tselentis BS 'Regional development and the islands of Kos and Rhodes - a study of sustainable financial opportunities' $2^{\text {nd }}$ Conference on sustainable planning and development Bologna 2005, Wessex Institute of Technology

[13] Prokopiou DG, MBA Dissertation: 'Regional Investment Study for Kos and Rhodes islands', University of Piraeus, 2005(in Greek)

[14] Papayanis T, 'Tourism carrying capacity in areas of ecological importance'

[15] Prokopiou DG and Tselentis BS 'Proposals for sustainable development and Environmental protection for the island of Rhodes', Rhodes 2003 (in Greek) 